\title{
多トラックスケールを用いた 絶対值リニアエンコーダの開発*
}

\author{
松 添 雄 二** 小泉 和 裕 $^{* * *}$ \\ Development of high parlance absolute linear encoder using the multi-track scale \\ Yuji MATSUZOE and Kazuhiro KOIZUMI

\begin{abstract}
Recent requirements for semiconductor equipment and robots that can proceed in their tasks without returning to a starting point have increased the demand for absolute encoders, including higher resolution and longer scale. This paper deals with the development of a high-resolution, long-range absolute linear encoder. To obtain the absolute position this encoder combines three signals: 1) the M-code signal, based on the 9-bit M-code; 2) the Gray-code signal, based on the 4-bit Gray code; and 3) the interpolation of data of sinusoid waves by the grating. This absolute linear encoder achieves an accuracy of $0.16 \mu \mathrm{m}$ and $1 \mathrm{~m}$ detection range.
\end{abstract}

Key words: Absolute encoder, linear encoder, long scale and resolution

\section{1. 緒言}

工作機械，ロボット，半導体検査装置などの水平搬送機構と して，1）ロータリモータとボールねじによって水平力に変換す る機構を設けたロータリサーボシステム，2）リニアモータによ り直接水平力を発生させるリニアサーボシステムがある.リニ アサーボシステムはボールネジ等の機械的な機構が不要なため, 高速・高精度な位置決めが容易である ${ }^{1) \sim 2)}$. このようなリニア サーボシステムに用いられる絶対值リニアエンコーダは特殊な 用途で用いられる場合が多く, その市場は限られていた. 近年, 半導体製造装置やロボットで原点復帰作業が困難なシステムに 対する要求が高まり, 原点復帰作業が不要な絶対值リニアエン コーダが要求されつつある ${ }^{3)}$.

一般に, 絶対值リニアエンコーダの位置検出手法として, グ レーコード方式 6) 8), バーニア方式 77 9) 10), M 系列方式 ${ }^{6) 111}$ など が報告されている. グレーコード方式やバーニア方式は長尺化 には適しているが, 高分解能を実現するためにはコードパター ンを増や寸ためスケールの幅を広げる必要があり, 高分解能化 には適さない.一方, $\mathrm{M}$ 系列方式は高分解能化には適しているが, 長尺化を実現するためには受光セルを増やす必要があり, 長尺 化に適さない. そのため, 高分解能と長尺化の両立が困難であ った.

本論文では，M 系列方式とグレーコード方式を組み合わせて， 高分解能と長尺化を両立する絶対值リニアエンコーダを開発し, スケール長 $1 \mathrm{~m}$, 分解能 $0.16 \mu \mathrm{m}$ を達成した.

\section{2. 絶対値検出原理}

\section{1 構成}

図 1 に絶対值リニアエンコーダの全体構成を示す。これは照 明用の LED, 位置情報がパターニングされたスケール, 受光素子 から構成される. LED から照明された光線は位置情報がパターニ

\footnotetext{
* 原稿受付 平成 16 年 03 月 31 日

** 正会員 富士電機アドバンストテクノロジー株（東京都 日野市富士町 1 番)

***＼cjkstart富士電機アドバンストテクノロジー株
}

ングされたスケール上のパターンを反射し, 受光素子にて検出 する.

図 2 にスケールの全体構成を示す。このスケールは格子トラ ック， M 系列トラック, グレーコードトラックの 3 つのトラック から構成される. 図 3 に図 2 の $\alpha$ 部を拡大したものを示す．格 子トラックは光を透過及び反射する格子を有するものであり, 通常のインクリメントリニアエンコーダではこのトラックのみ で機能を果たす．本絶対值リニアエンコーダではこの格子 1 ピ ッチを $0.16 \mathrm{~mm}$ に設定した.

M 系列トラックは M 系列に基づいてパターニングされたトラ ックである. ここでM 系列とは Maximum Length Sequence の最 初の M をとった M-Sequence の訳であって, 最大長系列または最 大周期列とも呼ばれる. 図 4 は 9bit の M 系列を示す. 図 4 に示 すように M 系列は， $2^{\mathrm{n}}$ 個の 1,0 の組み合わせで構成され簡単な 規則によって作られる確定的系列であるが外観上不規則な系列 である. M 系列の特定位置から連続する $\mathrm{n}$ 個の 1,0 情報(パター ン)は系列内で 1 つか存在しないため, $2^{\mathrm{n}}$ 個の重複しない情報 を持つ. 本絶対值リニアエンコーダで用いる M 系列トラックは M 系列の 1 を透過部，0 を反射部とする $2^{\mathrm{n}}$ 個の格子を有するトラ ックである．本絶対值リニアエンコーダでは, $\mathrm{n}=9$ に設定し $2^{9}$ 個（=512）の位置情報をもつた9bit のM 系列をもつパターンで ある. M 系列トラックの最小格子の長さは格子トラックと同じ $0.16 \mathrm{~mm}$ であり, $0.16 \times 512=81.92 \mathrm{~mm}$ の位置情報を持つ. スケ

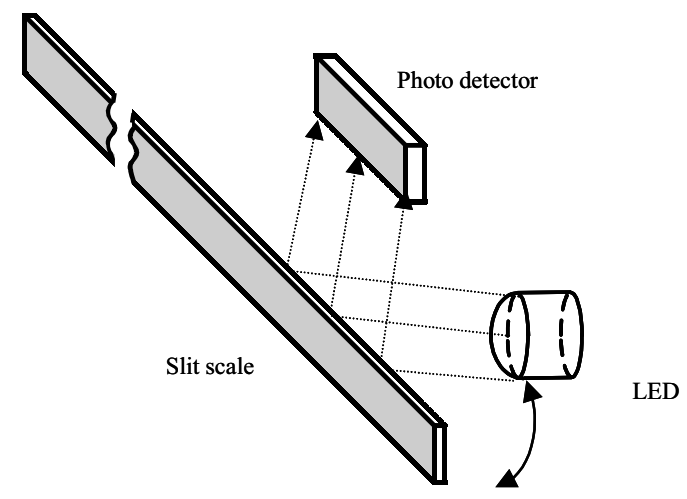

Fig. 1 Basic configuration of the optical encoder 


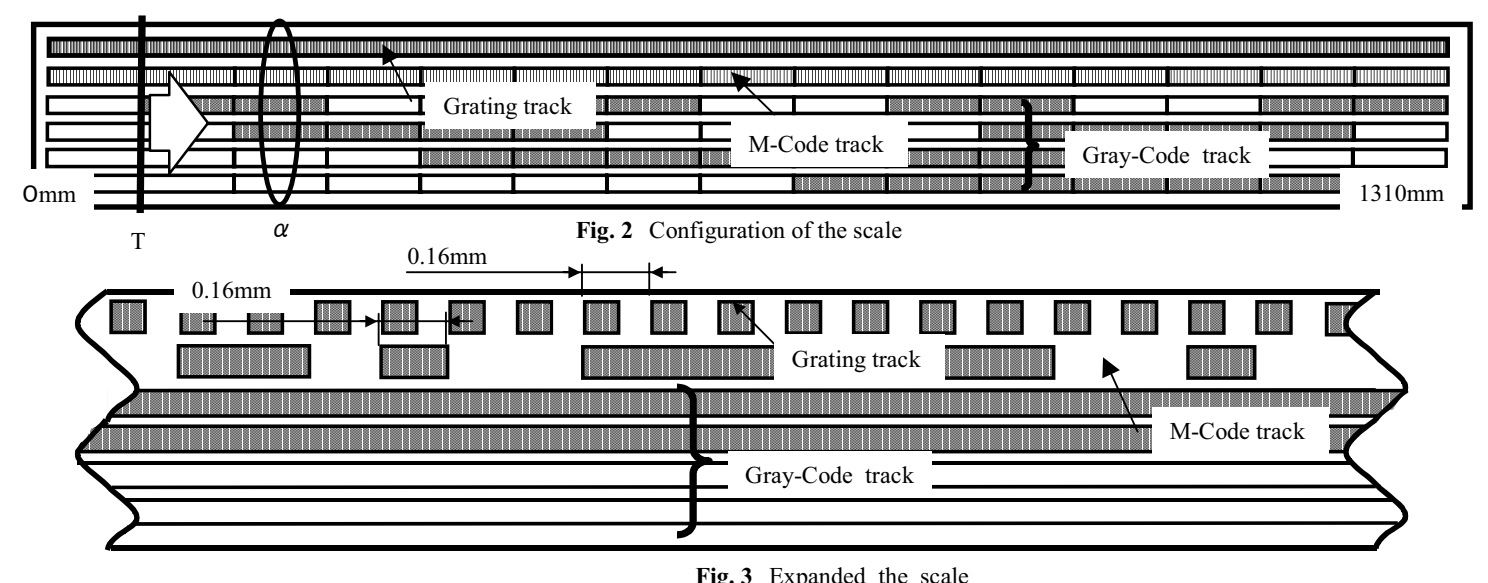

ール上には $81.92 \mathrm{~mm}$ 毎に繰り返し同じ $\mathrm{M}$ 系列パターンがパター ニングされている.ここで，M 系列の格子の長さを $0.16 \mathrm{~mm}, \mathrm{n}=9$ に設定した理由は，1) 照明用 LED の照明領域が $\phi 3 \mathrm{~mm}$ であり十 分に 9 個の M 系列による格子が照明できること, 2) LED の照明光 量と受光セルの大きさ，3) 回路系のカットオフ周波数からであ る.

グレーコードトラックはクレーコードに基づいてパターニン グされたトラックである。ここでグレーコードとは純 2 進バイ ナリコードと異なり，符号が同時に 2 つ以上変化しないコード である. 図 5 に $4 \mathrm{bit}$ のグレーコードを示す．グレーコードトラ ックはグレーコードの 1 を透過部, 0 を反射部とするトラックで あり, 本絶対值リニアエンコーダでは $\mathrm{G} 1$ ～G4 の 4 本のトラック, すなわち $2^{4}$ 個（=16）の位置情報を有する. 本絶対值リニアエン コーダでは M 系列からの信号が $0 \sim 2^{9} \quad(=512)$ まで信号が変化す る間, 寸なわち, $81.92 \mathrm{~mm}$ の位置変化に対してグレーコードから の信号が 1 ステップ変化するようにパターニングされており， $81.92 \times 16=1310.7 \mathrm{~mm}$ の位置情報を持つ. なお，今回開発したス ケールはスケールの製造装置の制約からスケールの長さは 1.0 $\mathrm{mm}$ とした.

図 6 に受光素子上の受光セルのパターン, 図 7 に受光素子の 回路構成を示す. 図中の斜線で示した領域は光を感じる感帯部 を示し，その他の領域はアルミにて遮光された不感帯領域であ る. 格子トラックの対向した位置に配置された PD1A, PD1B, PD1C 及び PD1D の 4 つの受光セルアレイは，それぞれ複数の受光セル から構成される. これらの受光セルのピッチは格子トラック上 の格子とほぼ同じ周期で配置されている ${ }^{12)}{ }^{13)}$. また各受光セル 間の周期を位相差 $360^{\circ}$ と定義すると, PD1A の受光セルアレイ の受光セルと PD1B の受光セルアレイの受光セルとの位相差は

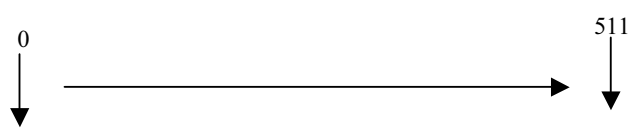

\section{$1010110 \cdots 1001110010$}

Fig. 4 M-Code

\begin{tabular}{c|c|c|c|c|c|c|c|c|c|c|c|c|c|c|c|c} 
& 0 & 1 & 2 & 3 & 4 & 5 & 6 & 7 & 8 & 9 & 10 & 11 & 12 & 13 & 14 & 15 \\
\hline G1 & 0 & 1 & 1 & 0 & 0 & 1 & 1 & 0 & 0 & 1 & 1 & 0 & 0 & 1 & 1 & 0 \\
\hline G2 & 0 & 0 & 1 & 1 & 1 & 1 & 0 & 0 & 0 & 0 & 1 & 1 & 1 & 1 & 0 & 0 \\
\hline G3 & 0 & 0 & 0 & 0 & 1 & 1 & 1 & 1 & 1 & 1 & 1 & 1 & 0 & 0 & 0 & 0 \\
\hline G4 & 0 & 0 & 0 & 0 & 0 & 0 & 0 & 0 & 1 & 1 & 1 & 1 & 1 & 1 & 1 & 1 \\
\hline
\end{tabular}

Fig. 5 Gray-Code $90^{\circ}$ ，同様に PD1A と PD1C との位相差は $180^{\circ} ， \mathrm{PD} 1 \mathrm{~A}$ と PD1D と の位相差は $270^{\circ}$ となるように配置されている. 各受光セルに到 達する受光量は非常に少ないため, 受光セルアレイ毎に 10 個の 受光セルは並列接続され電流を増やしている．更に，受光セル アレイのカソード側は逆バイアスになるように接続されており， 受光した光子に対して増幅した電流を得ている.

M 系列トラックの対向した位置に配置された PD2A 及び PD2B 受光セルアレイはそれぞれ M 系列の bit 数と同じ 9 個，合計 18 個の受光セルから構成される. 受光セルアレイ PD2A の左側から 受光セル PD2A1, PD2A2, ‥PD2A9 と称し, 受光セルアレイ PD2B の左側から受光セル PD2B1，PD2B2，・・PPD2B9 と称す。これ らの受光セルの周期は格子トラックの周期と同じであり，それ ぞれの受光セルは独立した合計 18 個の信号を出力する.この受 光セルは格子トラックのように複数の受光セルを並列接続して 用いていないため受光セル当たりの発生する電流が非常に小さ い．そのため，本絶対值リニアエンコーダでは受光素子上に配 置されたトランジスタアレイのベースと各受光セルのアノード とを接続し，各受光セルから得られた電流を増幅できる構成と した．また，PD2A と PD2B とから構成される受光セルアレイは, 格子トラックの格子周期を位相差 $360^{\circ}$ と定義したとき， $180^{\circ}$ 位相差になるようにそれぞれ配置されている。

グレーコードトラックの対向した位置に配置された受光セル

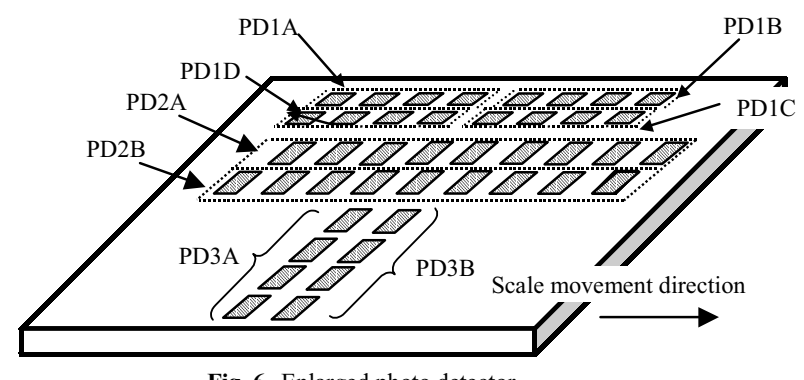

Fig. 6 Enlarged photo detecto

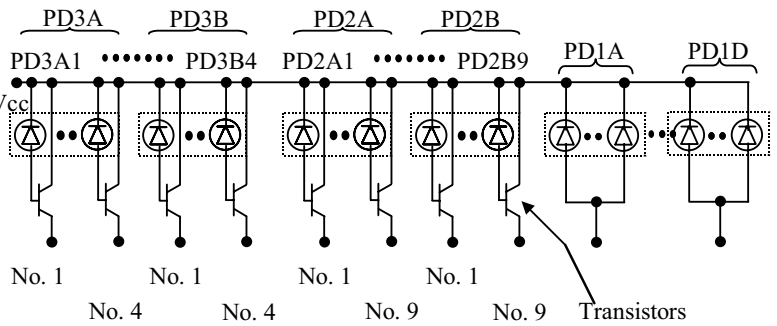

Fig. 7 Photo detectors circuit diagram. 


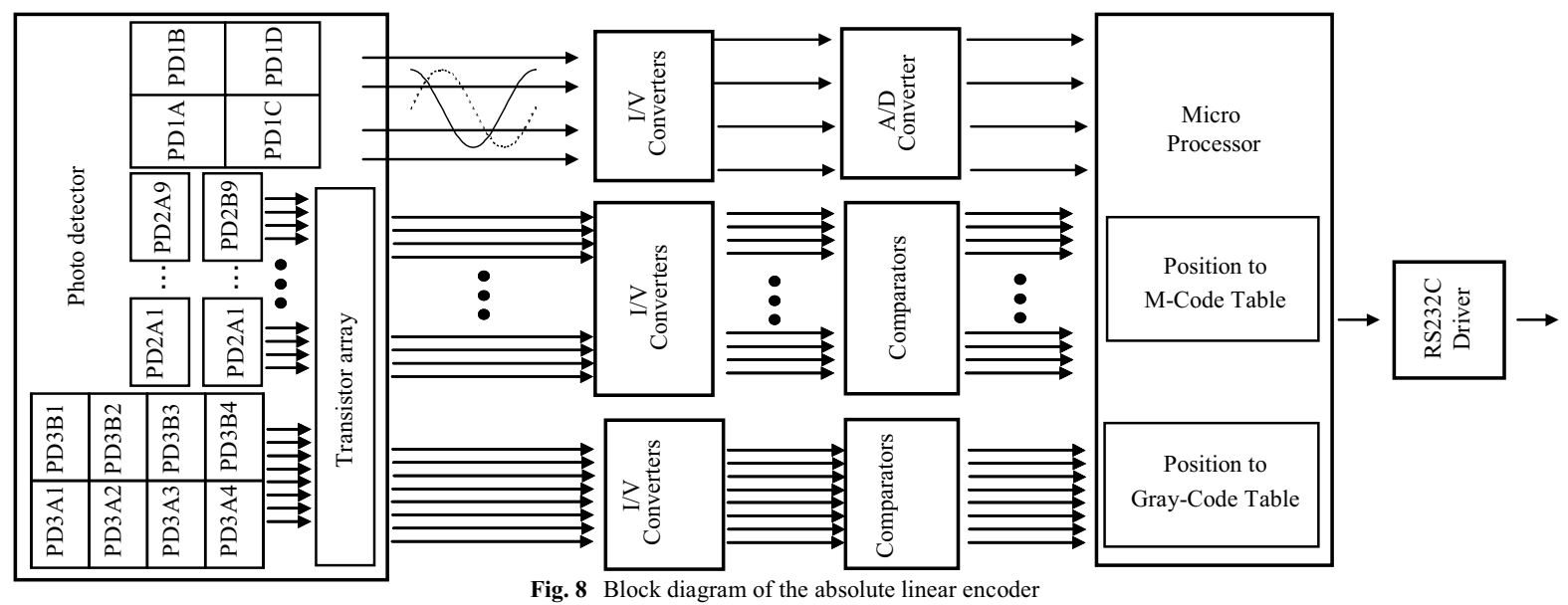

アレイ PD3A 及び PD3B は，それぞれグレーコードの bit 数と同 じ 4 個で，合計 8 個の受光セルから構成される. 受光セルアレ イ PD3A の上側から受光セル PD3A1, PD3A2, ‥PD3B4 と称し, 同様に受光セルアレイ PD3B の上側から PD3B1，PD3B2，・PD3B4 と称する。これらの受光セルはそれぞれグレーコードの各トラ ックの対向した位置に配置される. また, PD3A 受光セルと PD3B 受光セルとの間距離は格子トラックの格子ピッチと同じである. 受光セルアレイ PD2A 及び PD2B からなる受光セルと同様に, PD3A1〜PD3B1 の受光セルは其々トランジスタアレイに接続され 電流増幅できる構成とした。

図 8 に, 回路ブロック図を示す. 格子トラックの対向した位 置に配置されたPD1A〜PD1D 受光セルアレイは I/V 変換回路, A/D 変換回路を介してマイクロコンピュータに接続されている。一 方, PD2A1〜PD2B9 の 18 個の受光セルからの出力信号及び, PD3A1 ～PD3B4 の 8 個の受光セルからの出力信号は, 受光セルに内蔵さ れたトランジスタ, I/V 変換回路, 比較回路を介した後, マイク ロコンピュータに接続されている.

\section{2 動作}

次に本絶対值リニアエンコーダの動作について説明する．ス ケールの移動に伴い受光素子からは図 9 に示すような信号を出 力する. ここで, 図 9 は図 2 のスケール上 T の領域を矢印の方 向に移動した時の信号である, 横軸は時間, 縦軸は I/V 変換後 の信号振幅電圧ある. 図 9 において, PD1C, PD1D 及び PD2A2〜9, PD2B2〜9 の信号は図示されている信号と同様であるため表記を 省略した. 図 9 のタイミング $\mathrm{T}_{1}$ にて位置検出を行う場合, PD1A, PD1B 及び図示されていない PD1C と PD1D からの 4 つの正弦波電

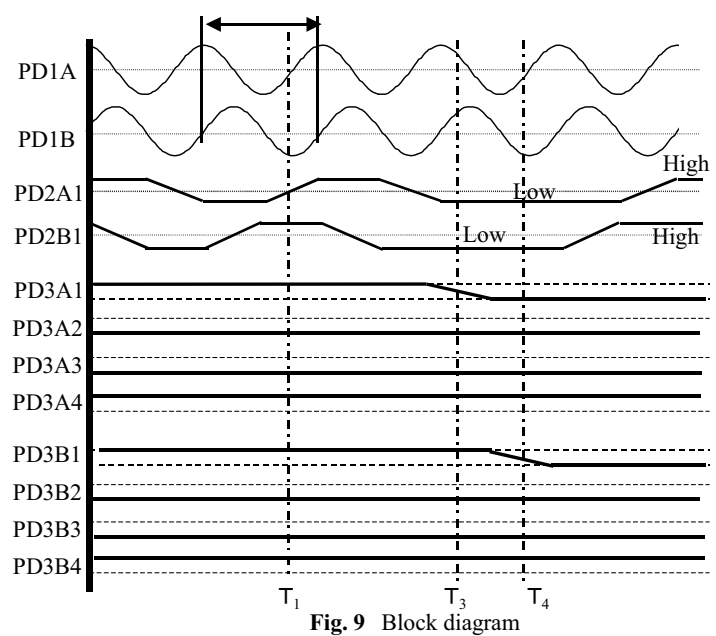

流信号は, I/V 変換回路に入力される. そして, I/V 変換回路に て電流信号から電圧信号に変換し, 式 (1)〜 (4) に示寸信号を出 力する.

$V_{\mathrm{A}}(\theta)=\mathrm{X}+\mathrm{Y} \sin (\theta)$,

$V_{B}(\theta)=X+Y \cos (\theta)$,

$V_{C}(\theta)=X-Y \sin (\theta)$,

$V_{D}(\theta)=X-Y \cos (\theta)$.

ここで $V_{A}, V_{B}, V_{C}, V_{D}$ は $\mathrm{I} / \mathrm{V}$ 変換回路後の PD1A〜PD1D の電圧信 号である. 上式の X はオフセット，Y は振幅である. 次に, I/V 変換回路からの出力信号は差動回路に入力され, 各信号の位相 差が $180^{\circ}$ ， 寸なわち逆相の関係にある $\mathrm{V}_{\mathrm{A}}$ と $\mathrm{V}_{\mathrm{C}}$ 及び $\mathrm{V}_{\mathrm{B}}$ と $\mathrm{V}_{\mathrm{D}}$ 信号 間で差動演算を行い, 式（5）及び（6）に示すような信号を得 る.

$V_{\mathrm{AC}}(\theta)=2 \mathrm{Y} \sin (\theta)$,

$\mathrm{V}_{\mathrm{BD}}(\theta)=2 \mathrm{Y} \cos (\theta)$.

差動回路の出力信号 $\mathrm{V}_{\mathrm{AC}}, \mathrm{V}_{\mathrm{BD}}$ は, $\mathrm{A} / \mathrm{D}$ 変換回路を介してマイクロ コンピュータに取込まれ，これらの信号を電気的に分割するこ とによって得られる内挿データを得る. 内挿データは式(8)で与 えられる.

内扫データ $=\tan ^{-1} \quad\left(\mathrm{~V}_{\mathrm{AC}}(\theta) \div \mathrm{V}_{\mathrm{BD}}(\theta)\right)$.

例えば，格子トラックの 1 周期が $0.16 \mathrm{~mm}$ なので $0.16 \mathrm{~mm}$ の格 子トラックの範囲寸なわち, 図 9 の $\beta$ の範囲において位置情報 を得ることができる. 本絶対值リニアエンコーダではマイクロ コンピュータで 1000 分割しているので，最小分解能 $0.16 \mu \mathrm{m}$ を得る.

次に, M 系列トラックから得られる M 系列信号から絶対值を得 る方法について説明する. 前述と同様にタイミング $\mathrm{T}_{1}$ において, 受光セル PD2A1〜PD2B9 の 18 個の出力信号は I/V 変換回路にて 電圧信号に変換され，比較回路にて High-Low の 2 值信号に変換 され，マイクロコンピュータに取り込まれる.ここで PD2A1〜 PD2A9 の受光セルに注目する. PD2A1〜PD2A9 で得られた連続す る 1 と 0 の 9bit の情報は図 10 に示すようなマイクロコンピュ

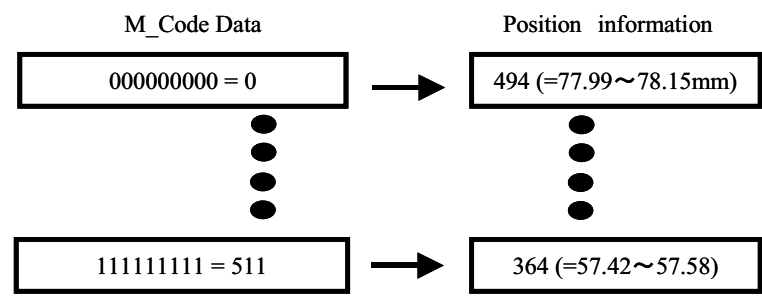

Fig. 10 M_Code to Position table 
一タ内に予め用意された M 系列一位置変換テーブルと照合し位 置情報を得る. 例えば, PD2A1〜PD2A9 からの信号の全てが High であれば, マイクロコンピュータ内では” 111111111”のM系列 データとして処理される. そして, M 系列一位置変換テーブルよ り 364 の位置情報を得る. 今，0〜511の 512 個の位置情報で 0 ８1.92 mm の範囲の位置情報が成り立っているので, 364 番目 の位置情報は 0 81.92 mm の範囲内の $57.42 \sim 57.58 \mathrm{~mm}$ の位置 情報を検出していることになる. 次に, 図 9 に示寸ような PD2A1 〜PD2A9 からの信号が 0 (Low)から 1 (High)に切り替るタイミン グ $\mathrm{T}_{1}$ では, 閾值レベルが安定しないため比較回路にて High 又は Low 信号を正しく判断することができない. そのため, M 系列に よる位置誤りが発生する可能性がある. そこで, 本絶対值リニ アエンコーダでは, 内挿データが $0 \sim 80 \mu \mathrm{m}$ までの範囲であれ ばPD2A アレイの PD2A1〜PD2A9, 逆に 80〜160 $\mu \mathrm{m}$ までの範囲で あれば PD2B アレイの PD2B1〜PD2B9 までの信号を採用すること により, 閾值レベルを間違えることなく安定して位置情報を得 ることが可能となるようなアルゴリズムを考案した.

最後に, グレーコードトラックに対向する位置に配置された 受光セルアレイ PD3A に注目寸る. PD3A から得られた $4 \mathrm{bit}$ 信号 をCPU 内に予め用意された図 5 に示すようなグレーコードー位 置変換テーブルと照合し位置情報を得る. 例えば，図 9 に示す タイミング $\mathrm{T}_{1}$ 場合では，マイクロコンピュータ内で “1000”の グレーコードデータとして処理される. そして, 図 5 に示すグ レーコードー位置変換テーブルより “1” の位置情報を得る. 今, $0 \sim 15$ の 16 個の位置情報で $0 \sim 1317 \mathrm{~mm}$ の範囲の位置情報が成り 立っているので, 1 番目の位置情報は $0 \sim 1317 \mathrm{~mm}$ 内の $81.92 \sim$ 163. 83mm の位置情報を検出していることになる. 次に, 図 9 の タイミング $\mathrm{T}_{2}$ にて位置検出を行う場合, PD3A1 からの信号はHigh
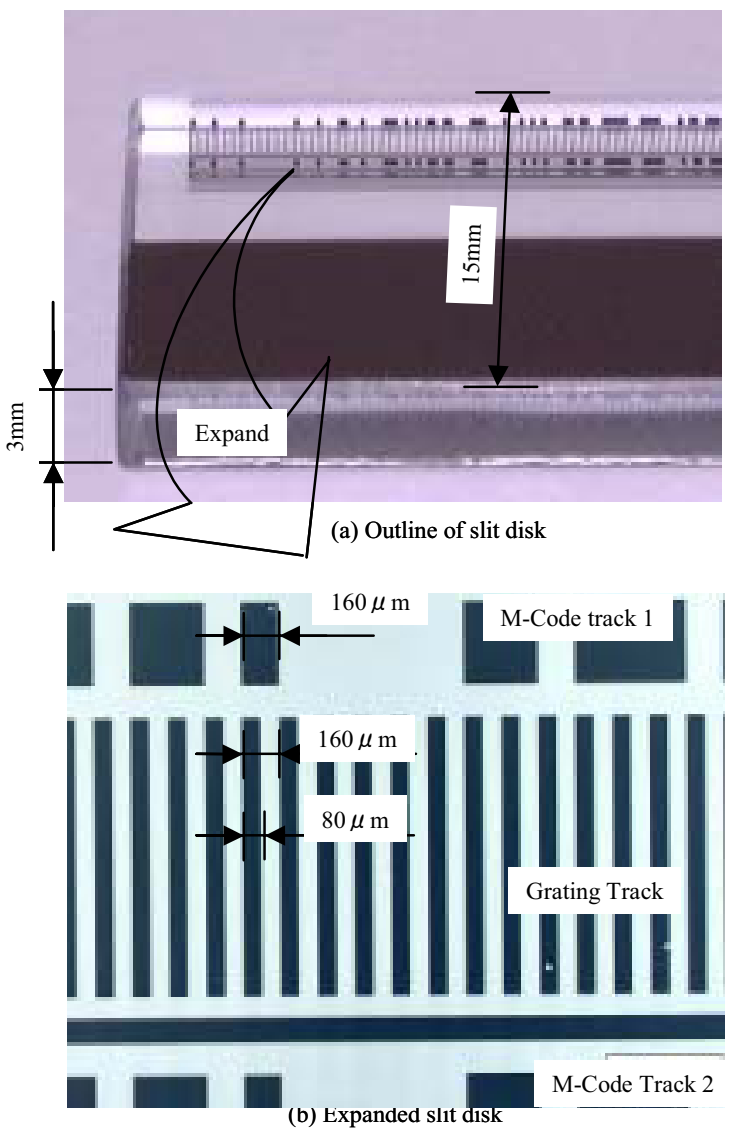

Fig. 11 Picture of the slit disk with an expanded view.
から Low に信号が変化するときであり, M 系列信号と同様に比較 回路にて High 又は Low 信号を正しく判断することができない. そのため, M 系列による位置誤りが発生する可能性がある. しか し, 図 9 に示寸ように M 系列の位置情報が 511〜255 までの範囲 であれば, 受光セルアレイ PD3A からの信号は比較回路にて High 又は Low の信号の誤りが発生する可能性はあるが，PD3B は安定 的な信号が必ず得られるので比較回路にて High 又はLow を誤る ことはない，逆に M 系列の位置情報が 0〜254 までの範囲であれ ば受光セルアレイ PD3A からの信号は, 比較回路にて Low と High の判断を誤ることはない。 よって，M 系列信号の位置情報が 0〜 254 であればPD3A を選択し, 255〜 511 までの範囲であれば PD3B を選択することにより，閾值レベルを間違えることなく安定し て位置情報を得ることが可能となる.

これら格子トラックから得られた 0 0.16 mm までの位置情報, M 系列トラックから得られた 0 81. $92 \mathrm{~mm}$ までの位置情報及びグ レーコードトラックから得られた 0 1310. $7 \mathrm{~mm}$ までの位置情報 をマイクロコンピュータで組み合わせて, エンコーダの絶対位 置を導出し, RS232C ドライバでシリアルデータに変換して出力 する.

\section{3. 試作エンコーダ}

図 11 ( a )にスケール端部の拡大写真を示す. スケール幅 $15 \mathrm{~mm}$, スケール長 $1 \mathrm{~m}$ ，厚さ $3 \mathrm{~mm}$ である，写真の下部の黒い領域はスケ 一ルをホルダに固定するための目印である. 図 11（b ）にスケー ルのパターン部を拡大したものを示す. 図 3 ではスケール上側 から格子トラック, M 系列トラックとグレーコードトラックと配 置したが，実際に試作したスケールのパターンは中心に格子卜 ラック，格子トラックの上下方向に M 系列トラック， M 系列トラ ックの上下方向に図示されていないグレーコードトラックをそ れぞれ配置した。

スケール照明用の LED はレンズ，レンズの焦点位置に配置さ れた発光素子及び筐体から構成され，レンズからはフラットな 光強度分布の平行光が出力されるように設計されている. しか し実際の LED は 1 ）レンズの収差，2）レンズの取り付け精度, 3 ) 発光素子に所定の面積を有する, などの理由からレンズの 中心部から照射される光は比較的安定した光強度分布を得るこ とができるが，レンズの外周部から照射された光は光強度分布 にむらが発生する．そこで，本絶対值リニアエンコーダでは， 内挿処理により高分解能を実現するための信号を得る格子トラ

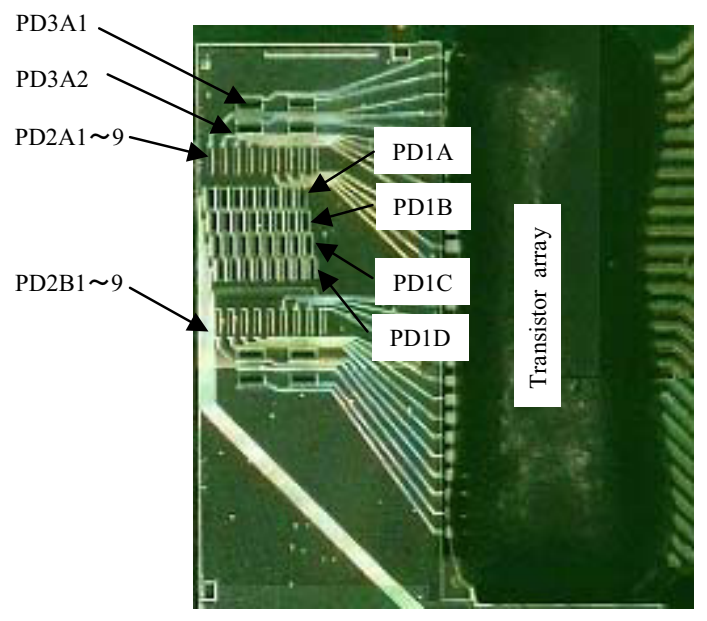

Fig. 12 Silicon photo detector 


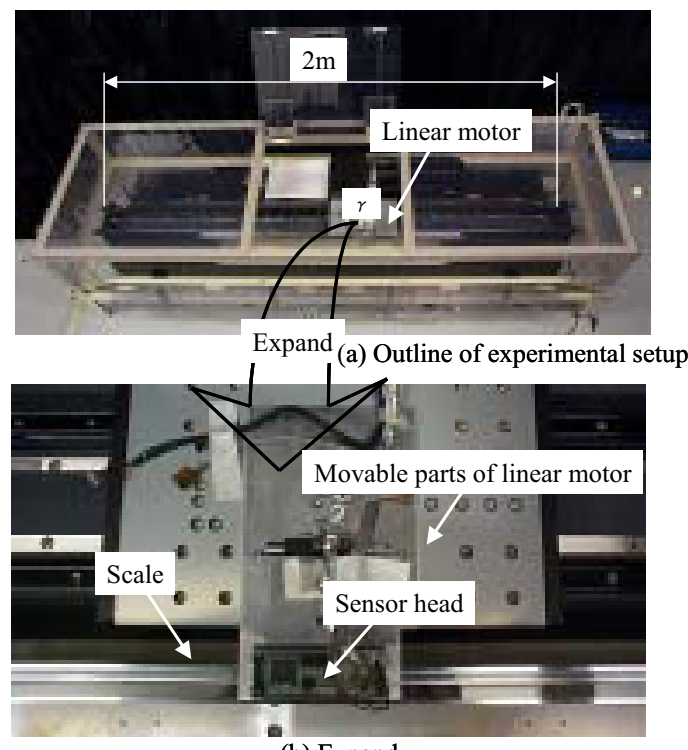

(b) Expand

Fig. 13 Photograph of the experimental setup

ックを光強度分布が安定している LED の照明領域の中心部に配 置し, High と Low の 2 值の位置情報で十分である M 系列及びグ レーコードトラックは照明領域の外周部に配置した. 図 12 に受 光素子の拡大図を示す. 受光素子は図 11 に示したスケールと対 向した位置に受光セルが其々配置されており, 図左側に PD2A1 〜PD2B9 及び PD3A1〜PD3B4 に接続されているトランジスタアレ イが配置されている．但し，トランジスタのベース側とのワイ ヤ配線を保護するために樹脂にてモールドしているため確認す ることはできない.

\section{4. 実験}

\section{1 評価装置}

図 13 (a)に今回試作した絶対值リニアエンコーダの評価装置 の構成を示す．この装置は, 石定盤上に配置されたリニアモー 夕, 図 13 (b) に示寸リニアモータの稼動部上にセットされたセン サヘッド，及びセンサヘッドの対向する位置に配置されたスケ 一ルから構成される。 ここで, リニアモータは, 図示されてい ない制御用パソコンからの速度と位置指令, リニアモータ付属 のインクリメントリニアエンコーダからの位置情報に基づき制 御される. また, センサヘッドは受光素子, マイクロコンピュ 一タ及びその周辺回路をプリント基板上に実装したものを筐体 に搭載したものである. センサヘッドからの位置情報は, 位置 情報としてパソコンに送られる．スケールは長さ $1 \mathrm{~m}$ に亘って スケールホルダ内に収納されており，スケールとリニアモータ の平行度は $10 \mu \mathrm{m}$ 以下に抑えている.

\section{2 実験結果}

図 14 にリニアモータを速度 $20 \mathrm{~mm} / \mathrm{s}$ で $1 \mathrm{~m}$ 移動させたときの リニアエンコーダの位置検出結果を示寸. 図下部の三角形の繰 返し信号はPD1A, PD1B と PD2A と PD2B, すなわち格子トラックと M 系列トラックからの位置情報に基づき位置検出值を演算した 結果である. PD1A と PD1B の内扱処理により分解能 $0.16 \mu \mathrm{m}$ を 得ることは可能であるが, これでは 0〜81.92 mm までの絶対值 位置情報しか得ることができず，それ以上の絶対值位置情報は 得られないことが分かる. そこで, 図中階段状の位置検出を行 っているグレーコードによる位置情報と, 先ほど述べた M 系列 信号及び内挿信号を組み合わせ，業界トップクラスのスケール

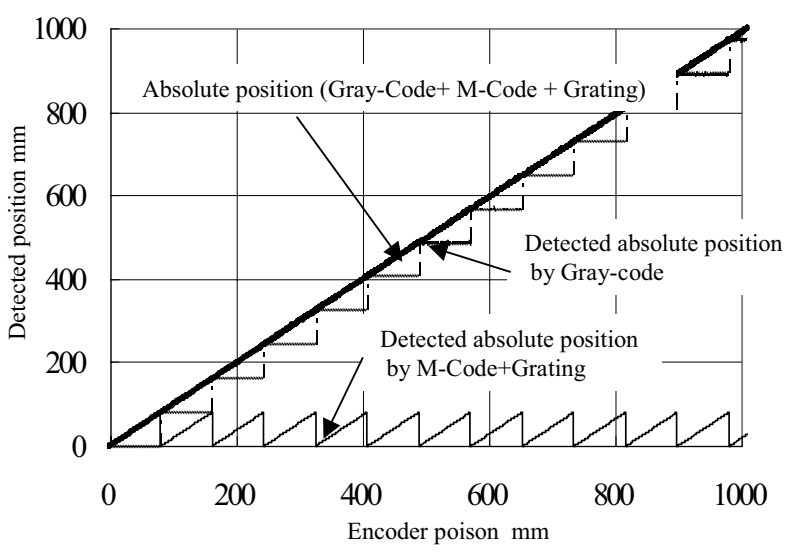

Fig. 14 Detection position of linear encoder

長 $1 \mathrm{~m}$ の位置検出を実現した. また, 分解能は図 14 に示す位置 検出值の幅に相当し, 一般産業用や半導体製造装置などで比較 的高精度な位置検出制御が可能な分解能 $0.16 \mu \mathrm{m}$ を実現するこ とができた。

\section{5. 結言}

M 系列とグレーコードの絶対位置情報と, 格子トラックを内挿 倍した位置情報を組み合わせた高分解能と長尺化を両立する絶 対值リニアエンコーダの絶対值検出手法を提案し, 下記の結果 を得た。

1）M 系列信号の位置情報に基づき，PD3A と PD3B の受光セルア レイを切り替えて使うことにより, 安定的に位置情報を得る アルゴリズムを開発した。

2) グレーコード信号, M 系列信号及びインクリメント信号を組み 合わせた位置検出アルゴリズムを開発し, 分解能 $0.16 \mu \mathrm{m}$, 絶対值位置スケール長 $1 \mathrm{~m}$ の絶対值リニアエンコーダを実現 することができた.

\section{参 考 文 献}

1) Seppo J. Ovaska, "Improving the Velocity Sensing Resolution of Pulse Encoders by FIR Prediction”, IEEE Transactions on instrumentation and measurement, 40, 3, (1991) 657.

2) N. Hagiwara, Y. Suzuki, H. Murase, "A method of improving the resolution and accuracy of rotary encoder using a code compensation Technique," IEEE trans. on instrumentation and measurement, 41, (1996) 98.

3）高坂始，“センサ選定・活用のポイント”，機械設計， 39, 12 , (1995) 26.

4）今井基勝, “光学式エンコーダの最新動向” ，センサ技術，10，8, (1990) 26.

5）熊田正次, 二宮祐司, 佐藤育美, 上山顕治, 長瀬喬, “小型・高性能 AC サーボモータ ミシリーズ”，技報 安川電機，56，2，（1992）144.

6) K. Fujita, T. Nakayama and Y. Matsuzoe, "Recent encoder technology," Fuji electric review, 46, 2, (2000) 57.

7) Frank Jay, "IEEE Standard Dictionary of Electrical and Electronics Terms", The Institute of Electrical and Electronics Engineers, Inc., New York, (1984) 999.

8）高野昌三，“ロータリエンコーダ”，機械設計，28，8，（1984) 114.

9) Sybil P.Parker, "DICTIONARY OF SCIENTIFIC AND TECHNICAL TERMS” , McGRAW-HILL BOOK COMPANY, New York, 828.

10）盛植昭彦, “変位を検出するセンサ”, センサ/計測モジュール活用 技術百科第 3 編， 170 .

11）柏木潤, “M 系列再発見”, 計測と制御，20，2，（1981） 42.

12）松添雄二, 小泉和裕, 斉藤哲哉, “エンコーダ光学系の最適設計変則受光セル周期による信号特性の改善”, 精密工学会誌春季大会 学術講演界講演論文集”，（2003） 85.

13）小泉和裕, 松添雄二, 斉藤哲哉, “光線追跡シミュレーションによ るエンコーダ光学系の最適設計”, 精密工学会誌秋季大会学術講演 界講演論文集”，（2002）213. 